\title{
It Looks Like a Hypocephalus, but It Is Not: Some Extraordinary Papyrus Fragments in the Museo Egizio (Provv. 6133)
}

\section{Ann-Katrin Gill}

This paper publishes for the first time and discusses a fragmentary papyrus in the Museo Egizio in Turin (Provv. 6133). It provides the repositioning of the fragments, a transliteration and translation of the text, and a commentary. It also provides some evidence that the original layout of the text on the papyrus was oval, with inscriptions from Book of the Dead spells and depictions of the so-called "entourage of Osiris" that are mainly known in this sequence from coffins and/or sarcophagi of the Late and Ptolemaic Period.

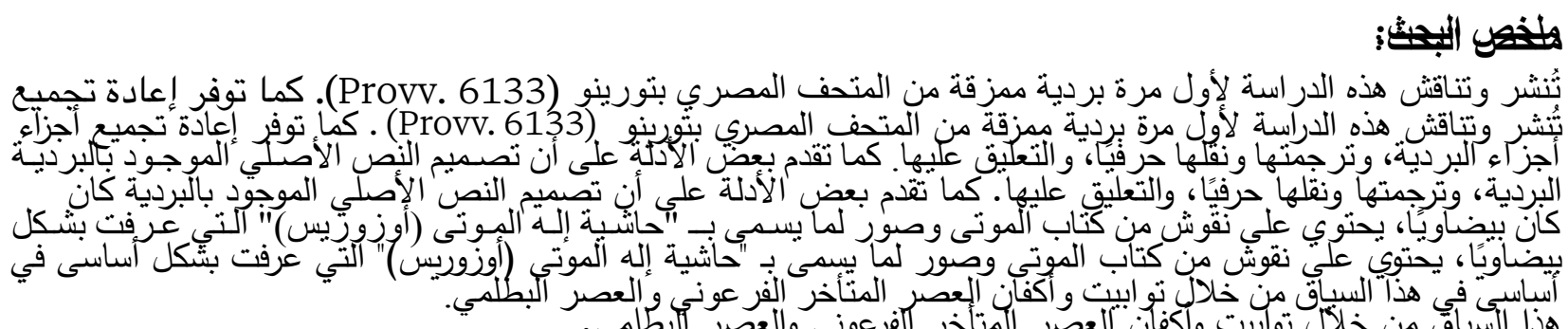

\section{Introduction}

Under the provisional inventory number Provv. 6133, the Museo Egizio in Turin houses a number of papyrus fragments ${ }^{1}$ (right-hand top fragment: $7.5 \mathrm{~cm} \mathrm{x}$ $11 \mathrm{~cm}$; right-hand middle fragment: $5 \mathrm{~cm} \mathrm{x} 11 \mathrm{~cm}$; right-hand lower fragment: $3 \mathrm{~cm} \times 4.5 \mathrm{~cm}$; left-hand upper fragment: $3.5 \mathrm{~cm} \times 4.5 \mathrm{~cm}$; left-hand lower fragment: $1.5 \mathrm{~cm} \times 3.5 \mathrm{~cm}$ ), light brown in colour. They are inscribed with texts in cursive hieroglyphs and decorated with several vignettes, drawn in black ink, in the typical style of Book of the Dead vignettes from the Ptolemaic Period. The writing as well as the drawings were executed with an extremely high degree of precision and fineness, with a lot of attention to detail. Many features are only fully visible with the help of a magnifying glass. Although only a small section of the complete papyrus is preserved nowadays, enough has survived to allow one to note that the overall layout and the arrangement of the texts and depictions are extraordinary. The present contribution to the Rivista del Museo Egizio intends to present these fragments with some suggestions as to their nature and to ensure their future accessi- bility to scholars for further study. ${ }^{2}$

Nothing is recorded about the acquisition of the object, besides the fact that it was acquired after 1824 . In the museum database, these fragments are ascribed to a hypocephalus. Although, at first glance, the curved lines and the arrangement of the texts and vignettes are indeed remindful of those of a hypocephalus, a closer examination argues against this, as the following investigation will show.

As it appears today (Fig. 1), the whole is composed of an "inner field" divided into registers. These registers contain vignettes with inscriptions and spells arranged in either columns or lines, separated from the figures by either single or double lines, drawn in black ink. To the right of this preserved "inner field" is a single column of text. The "outer circle" is composed of a mixture of figures and inscriptions, with the exterior black line used as a base line for the orientation of the figures and texts. Since only the right side of the inner vignettes and the surrounding columns/fields is preserved, it is not possible to determine whether the whole composition was symmetrical. It is likewise impossible to determine the 


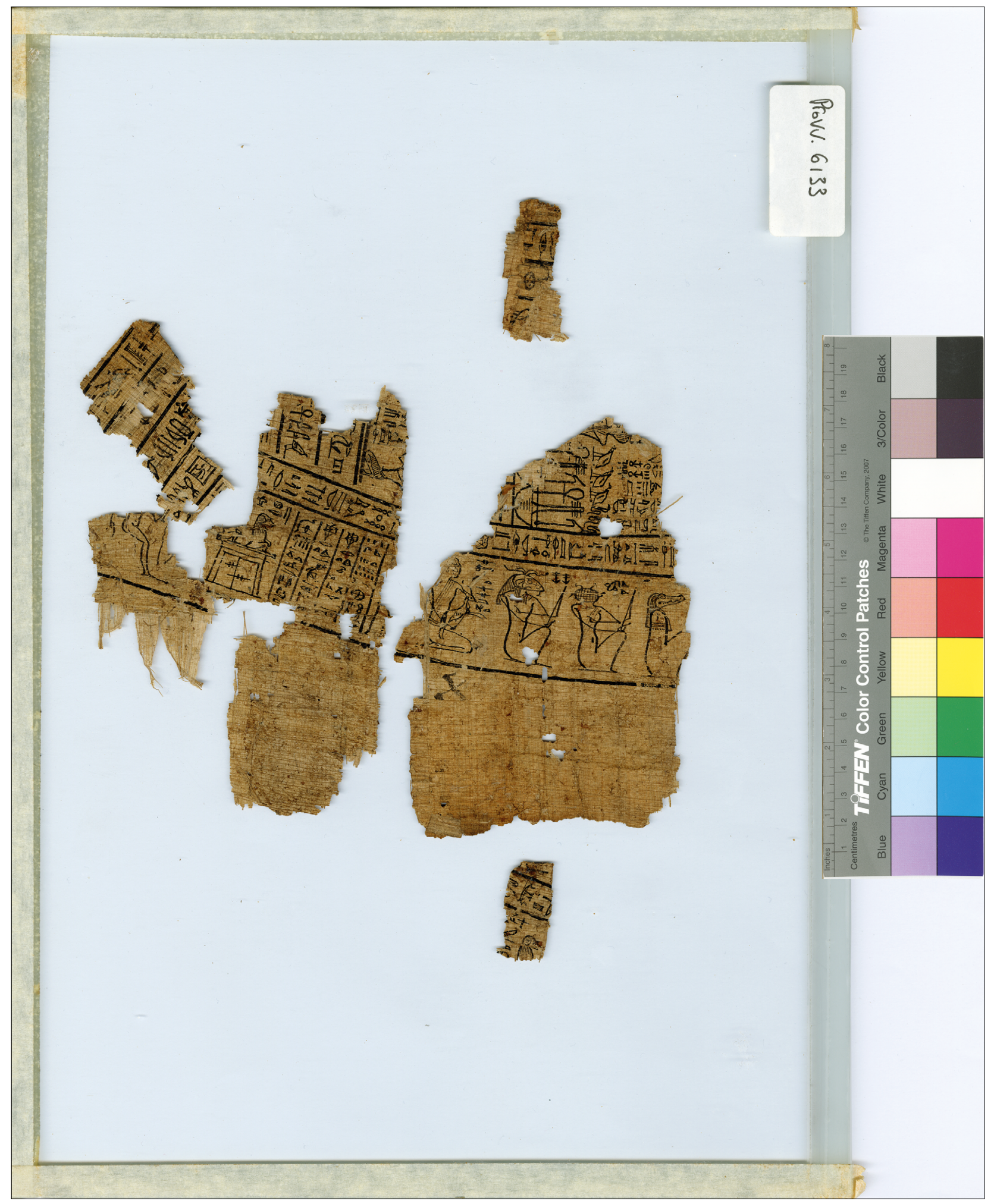

Fig. 1: Recto of P. Turin Provv. 6133 as currently mounted. Scan by Museo Egizio. 
original layout and shape of the composition with any certainty. A tentative reconstruction based on the investigation below suggests, however, that the original layout was oval, as the bend of the lines is not congruent with an exact circle.

The following study is divided into five main sections, the first dealing with the vignettes and inscriptions of the "inner field"; the second with the single column of text; the third with the "outer circle"; and the fourth with the annotation visible on the upper right-hand fragment. A general discussion of the possible content and nature of these papyrus fragments concludes the article.

\section{The vignettes and inscriptions of the "inner field"}

Only a small section of what I refer to as the "inner field" is preserved today. The upper register consists of a vignette showing the deceased standing with his arms raised in adoration, most likely in front of one or more deities. Although the figure is mostly destroyed, it appears as if he is also shown with $k_{3-}$ arms on his head. Behind the deceased is a pictorial double writing of ' $n h \underline{d} \underline{d} d$ wss $n b$ "all life, duration, and power", and above are three vultures and three snakes, i.e. animals that typically occur on magical papyri. ${ }^{3}$ At the top edge of the vignette, traces of ink are preserved, which might belong to the outstretched wing of a hovering vulture, ${ }^{4}$ as can be regularly seen in temple scenes, for instance. All of this must be understood as a symbol of an all-encircling protection, ${ }^{5}$ a motif that is discussed in more detail below, in the section on the "outer circle".

The lower part of an inscription is preserved in the upper right corner, behind the depiction of the deceased and above the three vultures and the three snakes. It reads as follows:
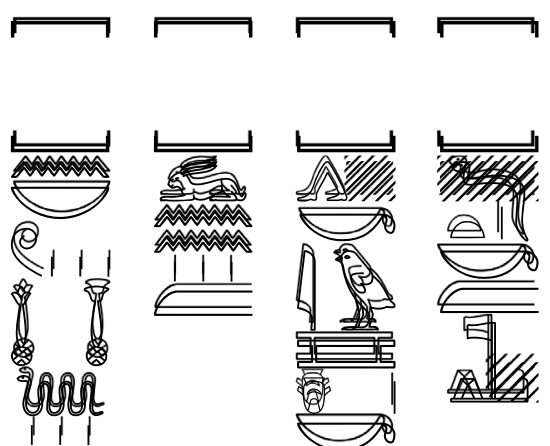

${ }^{1}[\ldots] n n b . w / n b . w t s ̌ m e . w m h . w / t 3 . w j{ }^{2}[\ldots]$ wnn.w $m^{3}[\ldots$ $c k(?)]=k^{6} r m r j j b=k^{4}[\ldots] \underline{d} . t(?)^{7}=k m \underline{h r} r . t-n \underline{t} r$

" $[$ [...] of/for the lords/ladies of Upper and Lower Egypt/the Two Lands ${ }^{8}$ [...] the ones who exist in/ on $[\ldots]^{3}[. .$.$] may you [enter(?)] according to what your$ heart desires ${ }^{4}[. .$.$] your body(?) in the necropolis."$

Below, separated by a black line, is the beginning of another text that is also arranged in columns. Apart from a presumed $n$-sign at the beginning of the right-hand column, everything is lost.

The lower register depicts the deceased kneeling, his hands raised again in adoration. Part of an inscription providing his name and the final signs of the name of his mother are still preserved:
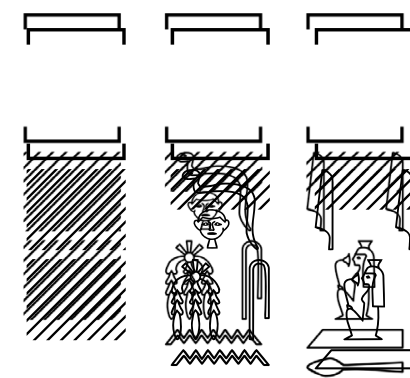

\section{${ }^{1}[\ldots]^{2}[\ldots] D d-h r$ msj. $n^{3}\left[\right.$ Tglm] $\left.y m_{3}{ }^{e} . t\right)-h r w$}

"1[... ${ }^{2}[. .$.$] Djedher, whom { }^{3}$ [Teglem]y, justified, has born"

Below this vignette, the beginnings of two lines of text are visible, which are, however, too fragmentarily preserved to allow a reconstruction of the context or an identification of possible parallels:

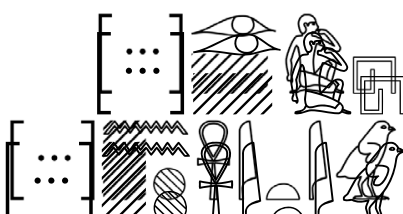

${ }^{1} h(3) W \operatorname{sjr}(?)[\ldots]^{2} w y . t$ ' $n h[\ldots]$

"1Hail Osiris(?) [...] " 2 live[...]"

Below this section, separated by a black line, there seems to be another vignette. However, traces of ink are only preserved in the upper corner and might belong to an accompanying inscription with the $\sqsubset$ -sign still partially visible.

\section{The single text column and its contin- uation}

The spells inscribed on the fragments - at least on those of which enough is left to allow their identification - can all be ascribed to the Book of the Dead. 
The long column running along the right side of the "inner field" is part of Spell 1 of the Book of the Dead. This column - combined with the decoration of the "outer circle" - allows the two larger fragments to be placed in their original position. The text can be restored and read as follows (the underlined passages are not attested in the parallels):
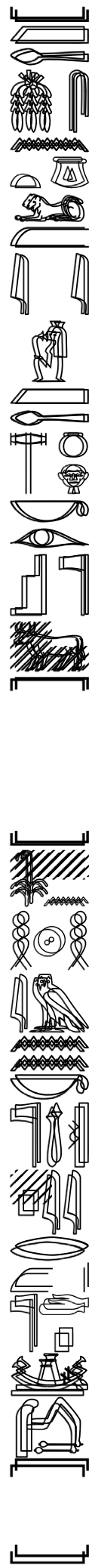

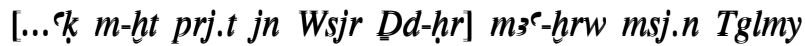
$m 3^{e}(. t)-h r w$ jnd-hr $=k$ Wsjr k3[-jmnt.t j.n Dhwwtj n] nsw.t

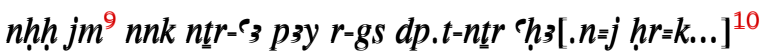

“[...Entering after going forth by the Osiris of Djedher], ${ }^{11}$ justified, whom Teglemy, ${ }^{12}$ justified, has born. 'Hail to you Osiris, bull [of the West', says Thoth] there [to] the king of the $n h h$-eternity, 'I am the great god, that one, beside the god's bark. [I have] fought [for you...]"”

The spell continues at a later point with two columns (hieroglyphs oriented to the left) preserved on another two fragments which my reconstruction places in the central part of this manuscript, inside the "inner field". These can be positioned within the text as follows:

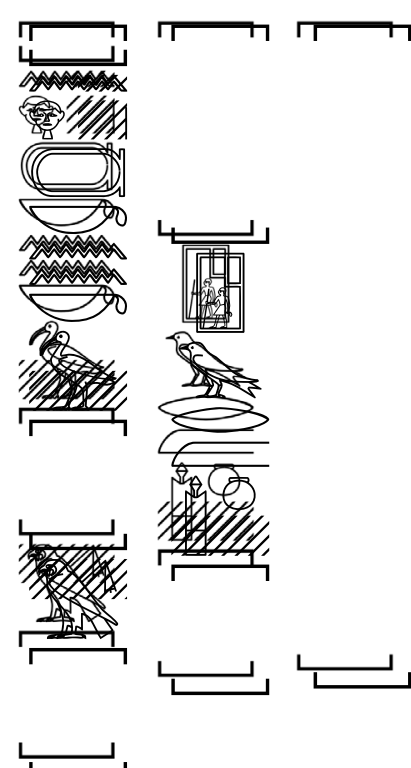

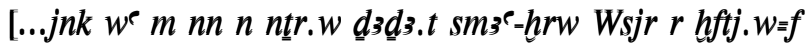
hrw pwy $n$ wdי $\underline{d}^{\complement}-m d . w t n-w j$ wnd $w$. $w(t)=k$ Wsjr jnk $w^{\complement} m$ nn $n$ ntr.w ms.w Nw.t smz hftj.w n.w wrd-jb hnr sbj.w

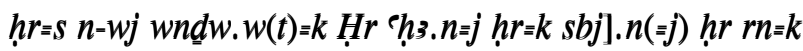

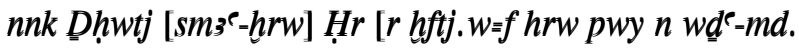
wt $m]$ h $h$ w.t-sr wr $m$ Jwn[w... $]^{13}$

"[...I am one of these gods of the council, who justify Osiris against his enemies (on) this day of judging. I belong to your people, Osiris. I am one of these gods whom Nut has born, who slay the enemies of the one with weary heart and who imprison those who rebelled against it/her(?). I belong to your people, Horus. I have fought for you.] (I) have [defended/stood up] for your name. I am Thoth [who has justified] Horus [against his enemies (on) this day of judging in] the great house of the magistrate in Helio[polis...]” 
The two columns to the left of those belonging to Spell 1 of the Book of the Dead are oriented in the opposite direction.

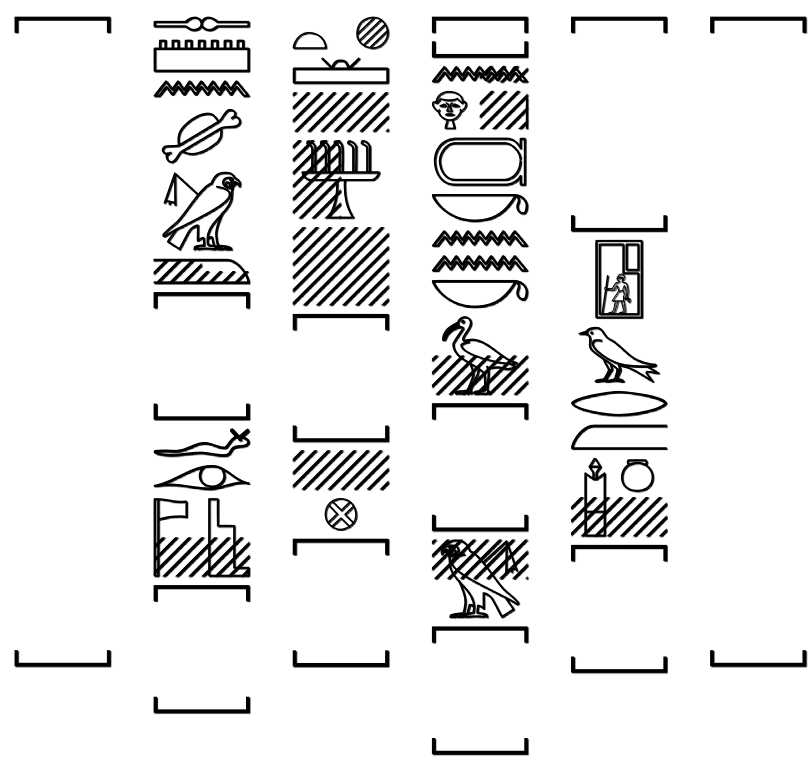

The surviving text could belong to any of the following four different formulas: Book of the Dead Spells 18,19 , or 20 , or the First Letter of Breathing. The three Book of the Dead spells are very similar in their content, with Spell 18 consisting of a series of invocations to Thoth intended to justify the deceased in front of ten netherworld tribunals. Spells 19 and 20 are similar in content and likewise connected with the tribunals, bearing the title "Formula/Another formula for a garland of justification" in the later versions. $^{14}$

Book of the Dead Spell 18 and the First Letter of Breathing contain the two relevant passages, but the amount of text between them is too long and does not fit the arrangement or length of the columns on the fragments from the Museo Egizio. ${ }^{15}$ The two remaining possibilities, Book of the Dead Spells 19 and 20 , do fit the length of the columns in this area of the Turin papyrus. The passage can thus be reconstructed as follows (the texts of Book of the Dead Spells 19 and 20 in this section are identical; the passages preserved on the Turin fragments are underlined):

Book of the Dead Spell 19 [...m-b3h $\underline{h} \underline{d}_{3} \underline{d}_{3 . t}$ c$_{3 . t} \mathrm{jmj} . \mathrm{w}$

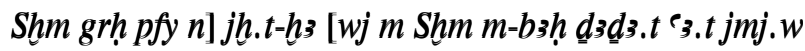
P Dp grh pfj $n]$ smn jw`w Hr m [jh.t jt] $=f$ Wsjir [m-b3h

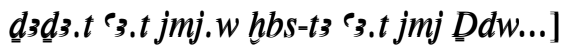

Book of the Dead Spell 20 [...m-b3h $\underline{d}_{3} \underline{d}_{3} . t$ `3.t jmj.w

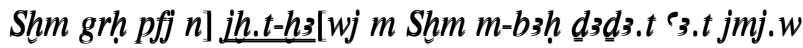

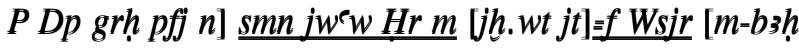

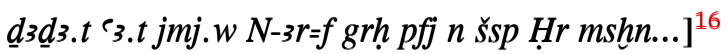

Translation of the passage in Book of the Dead Spell 19 or 20: "[....in the presence of the great council, which is in Letopolis, (on) that night of] the night offerings [in Letopolis, in the presence of the great council, which is in Pe and Dep, (on) that night of] confirming the heritage of Horus from/namely [the things/possessions of] his [father] Osiris [in the presence of the great council which is in the great hacking up of the earth which is in Busiris... / which is in Naref (on) that night of Horus receiving the abode...]"

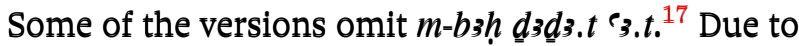
the estimated size of the lacuna - based on the reconstruction of Book of the Dead Spell 1 above - it seems very likely that this was also the case in the Turin papyrus.

If we assume that the original arrangement of the manuscript was symmetrical, it seems very likely that Book of the Dead Spell 19 or 20 occupied the single column to the left of the "inner field" and was then continued in the inner section just like Book of the Dead Spell 1 on the right-hand side. Book of the Dead Spell 1 is oriented from left to right, the signs facing the inner section. The hieroglyphs of Book of the Dead Spell 19 or 20 are oriented in the opposite direction and are hence the mirror image of Book of the Dead Spell 1. Thus, if we assume that Book of the Dead Spell 19 or 20 was the left-side equivalent of Spell 1 on the right side, both facing the "inner field", this would explain the orientation of the signs.

\section{Vignettes and inscriptions of the "out- er circle"}

\subsection{Some general remarks on protective entities}

The "outer circle" - if we assume that the original arrangement was oval - is dominated by a group of demons or divine entities, some of whom hold knives in their hands, reminding one of the typical depictions of apotropaic figures in the Book of the Dead that are responsible for guarding the gates or 
passageways of/to the underworld, such as Book of the Dead Spells 144-147. ${ }^{18}$ These depictions are also reminiscent of the so-called vignette of Book of the Dead Spell 182. In this spell, Thoth plays a prominent role in the protection and resurrection of Osiris. In P. BM EA 10010, dating to the Twenty-first Dynasty, Book of the Dead Spell 182 is followed by a vignette showing the funerary bed with the mummy of Osiris, flanked by Isis and Nephthys, and the four sons of Horus. Additional protection is provided by a series of figures holding knives, serpent staffs and lizards in their hands in the registers above and below. ${ }^{19}$

The specific row of entities in the particular order they appear in on the Turin fragments is attested elsewhere. I would first like to draw attention to some of these parallels - as far as they are known to me - before going into a more detailed discussion of the guardians of the Turin papyrus. According to the classification developed by Carolina Teotino, the divinities drawn on our fragments are part of the so-called "group of gatekeepers" or “Torwächtergruppe". ${ }^{20}$ As noted above, these protective figures appear in various numbers and in different orders in a multitude of texts and on diverse objects. However, the specific arrangement of the group of entities present on the Turin fragments is part of a socalled canonised form that seems to have developed at some point in the later phase of Egyptian history. The demons are attested in this fixed order on the following coffins and sarcophagi (listed chronologically): ${ }^{21}$

- Left $\operatorname{side}^{22}$ of the box of the sarcophagus of Psusennes I (Cairo JE 87297; originally made for Merenptah) Twenty-first/Nineteenth Dynasty; Tanis; with the names of the demons. ${ }^{23}$

- Left side of the box of the coffin of Horaawesheb (BM EA 6666); Twenty-second Dynasty; Thebes; no mention of the demons' names. ${ }^{24}$

- Left side of the box of the coffin of Ankhefenkhonsu (BM EA 30721); Twenty-second Dynasty; Thebes; with names. ${ }^{25}$

- Left side of the box of the coffin in the Museo del Vicino Oriente in Rome (E 1000); Twenty-fifth Dynasty; Thebes; with names. ${ }^{26}$

- Left half of the vaulted lid of the coffin of Ankhefkhonsu (Cairo CG 41001bis); around 664-332 BC; tomb of the Month priests in Deir el-Bahari; with names. $^{27}$

- Right side of the box of the sarcophagus of Ahmose (Ermitage 766); Twenty-sixth Dynasty; Giza, tomb LG 83; with names. ${ }^{28}$

- Second register on the left side of the box of the sarcophagus of Khafy (Cairo JE 49531); Ptolemaic Period; Saqqara; with names. ${ }^{29}$

- Second register on the left side of the box of the sarcophagus of Ankhhapi (Cairo CG 29301; JE 17249); Ptolemaic Period; Saqqara; with names. ${ }^{30}$

- Upper register on the left side of the box of the sarcophagus of Ankhhapi, son of Tefnakht (Cairo CG 29303; JE 15011); Ptolemaic Period; Saqqara; with names. $^{31}$

- First register on the left side of the box of the sarcophagus of Djedher (Cairo CG 29304; JE 15039); Ptolemaic Period; Saqqara; with names. ${ }^{32}$

- Right side of the lid of the sarcophagus of Wennofer (Cairo CG 29310; JE 8394), distributed across two registers ( $7^{\text {th }}$ and $\left.8^{\text {th }}\right)$; Ptolemaic Period; Saqqara; with names. ${ }^{33}$

The sarcophagus of Psusennes (Merenptah) constitutes the earliest known example of the canonised form of this group. ${ }^{34}$ This is also the only known example restricted to the royal sphere; later on, this decorative programme became available for private individuals. In addition to their widely attested canonised arrangement, these demons are also present, in diverse constellations and group sizes, on different media. Although in a bad state of preservation, several of the entities can still be identified on the sarcophagus of Hornakht from Tanis dating to the Twenty-second Dynasty. ${ }^{35}$ Furthermore, an unpublished Ptolemaic Period coffin belonging to one Horkawy, of unknown provenance (Brussels E. 7042), displays a number of protective figures, including some of those on the Turin fragments. ${ }^{36}$ Several of the demons also appear on the lid of the sarcophagus of Panehemisis from Saqqara (Vienna, Kunsthistorisches Museum $\ddot{A} S 4),{ }^{37}$ dating to 199$100 \mathrm{BC}$, and on the lid of the sarcophagus of Horemheb (Cairo TR 22/1/21/3-4). ${ }^{38}$ Also worth mentioning are the depictions of several of these protective beings on the Twenty-sixth Dynasty naos of Amasis (Leiden AM 107) from Sais. ${ }^{39}$ Finally, some of them are included in the procession of divine and protec- 
tive figures in the soubassement of the third eastern Osiris chapel in the temple of Dendera. ${ }^{40}$

In addition to these examples, the apotropaic figures appear on tomb walls from the New Kingdom onwards and are also placed as actual figurines inside tombs. ${ }^{41}$ They can be found on the walls of several tombs in the Queens' Valley and in the burial chamber of Ramesses III (KV 11). ${ }^{42}$ Some are also present in the vestibule of the tomb of Psusennes I (Twenty-first Dynasty) in Tanis. ${ }^{43}$

TT 410, the tomb of Mutirdis from the Twenty-sixth Dynasty, constitutes an example of the appearance of the canonised form of these entities on tomb walls. Two rows of seven chapels, each with the relevant protective figure or pair of figures inside, can be seen in the bottom section of the longitudinal east and west walls of the sarcophagus chamber. ${ }^{44}$ According to Assmann,

“die Darstellung der 14 Kapellen an den Längswänden bezieht sich auf einen Raumgedanken, der in dreidimensionaler Form in den Sargkammern der Gräber des Petamenope und des Montuemhet ausgeführt wurde. Dort sind die 14 Kapellen zu je 7 an den Längswänden als Nischen ausgestaltet, die bei Montemhet sogar mit den Statuetten der Dämonen besetzt waren.”45

Specimens of actual wooden figural representations of some of these protective entities came to light in several royal tombs of the Eighteenth and Nineteenth Dynasties - Horemheb, Ramesses I, Sety I, and Ramesses IX - the majority of which are nowadays housed in the British Museum. ${ }^{46}$ Their black colour symbolises fertility and resurrection. ${ }^{47}$

In addition to these wooden representations, figurines carved out of stone are preserved as well, such as the ones from the tomb of Montuemhat in the Asasif (TT 34) - mentioned above in the citation from Assmann - dating to the time of Taharqa and Psammetik I (Twenty-fifth-Twenty-sixth Dynasty). ${ }^{48}$ They were originally arranged around the sarcophagus in holes carved into the walls of the burial chamber. $^{49}$

As the above discussions show, although the protective entities present in the "outer circle" of the fragments from the Museo Egizio are recorded on differ- ent media in different forms, whether individually or in smaller groups partially similar to the Turin group, the specific canonised order of these demons that appears on the Turin fragments is to my knowledge only attested on coffins and sarcophagi. The only exception is the tomb of Mutirdis, where they are shown in this particular order, but separated into smaller groups housed in little chapels. The above list also shows that the earlier attestations of these figures, whether as statues or tomb-wall decoration, were initially restricted to the royal sphere and only later became available to private individuals.

The demons are usually represented along the long and short sides of sarcophagi and coffins, thus completely surrounding the mummy of the deceased, forming an all-encompassing protective circle. The following inscription describing the entities that are also present on the Turin fragments is provided on the sarcophagus of Psusennes I: ...jry ery.t $h r$ Wsjr s3w.w ery.wt=sn smj.w hr.t t3.wj $n$ Wsjr re-nb “... who perform the gatekeeping for Osiris, who guard their gates, who report the requirements of the Two Lands to Osiris every day". ${ }^{50}$

This row of apotropaic figures enclosed the whole of the coffin and as such also the mummy of the deceased and thus served as a protective barrier against any possible evil or harm that might threaten the deceased. This idea of being ready at all times to ward off evil and help the departed is further highlighted by the way some of the figures are depicted, namely in the semi-seated position with the legs bent at 90 degrees at the knees (as in the hieroglyph representing the "seated child"), ${ }^{51}$ but without a seat for them to actually sit on, giving the impression that they are sitting on air. ${ }^{52}$ Taylor proposes that this posture is intended to highlight their readiness. In other cases, these entities are depicted standing, kneeling, or squatting with their knees drawn up. Assmann suggests understanding the so-called m3s.w / m3stj.w "the kneeling/squatting ones" in the Coffin Texts as the precursors of these protective figures. ${ }^{53}$ There they are strongly connected with the protection of Osiris and characterised in the following way: $j r$

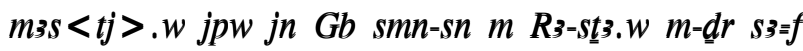
Wsjr $n$ snd $s n=f S t \check{s} \ldots$ jr sj $n b$ rh $r n n m_{3 s}<t j>$. w jpw $w n n=f h n^{e}$ Wsjr $r$ nhh $n j s k . n=f \underline{d} . t$ "As to these squatting ones: Geb is the one who made them firm in 
Rosetau in the area of his son Osiris, for fear of his brother Seth ... As to every man who knows the name of these squatting ones, he will be together with Osiris forever and never perish." ${ }^{54}$

With this idea in mind, one wonders whether the specific placement of these protective figures in the "outer circle" of the fragments - assuming that the original arrangement of the Turin papyrus was oval - was based on the same idea of a protective enclosure, this time for the inner sections depicting the deceased. Here, too, as on coffins, the figures enclose the deceased, except that in this case it is a pictorial representation of him rather than his actual mummy.

\subsection{The specific "Turin group"}

$1^{\text {st }}$ and $2^{\text {nd }}$ figures:

The first demon preserved on the Turin fragments has a crocodile head and originally held a knife on its drawn-up knees. ${ }^{55} \mathrm{As}$ is the case with the following figures, we can assume that its name was in a caption in front of its head, which is, however, lost today. Nevertheless, parallel groups indicate that it is most likely $H s f-m$-tp-r. ${ }^{56}$ In addition to attestations in the standardised groups mentioned above, this demon is also depicted with a crocodile head on one of the side walls of the naos of Amasis. ${ }^{57}$ Based on parallels, it is preceded by one more figure belonging to this specific entourage, $R s-j b$, "the one with a vigilant heart", who is usually depicted with a lion head and standing with one hand raised in a reciting pose as a means of introducing the procession that follows. ${ }^{58}$

$3^{\text {rd }}$ figure: 0

The figure of the second preserved demon (third in the complete group) has survived intact. It has a turtle in lieu of a head and holds a knife in its right hand, while the left arm is bent and the hand placed on the chest. The inscription identifies this being as Wnm- $h w 33 . t .{ }^{59}$ This name is likewise attested in Book of the Dead Spells 144 and 147, both variants of the same spell, which concerns the gates of the netherworld and their keepers. ${ }^{60}$ There, this name is the designation of the one who is at the third gate: Wnm$h w 3 . t-n . t-p h=f$ "eater of the excrement of his posterior" ${ }^{61}$ It is also depicted in the third eastern Osiris chapel in the temple of Dendera in a row of protec- tive entities, once again turtle-headed in a squatting position with a knife in its right hand, but placed on top of a dais this time. ${ }^{62}$

$4^{\text {th }}$ figure: $\theta 6$

The fourth demon has the head of a ram and the same posture as the previous figure, likewise with a knife in its hand. It bears the name $N f r-n f r . w^{63}$ and is also attested in the third eastern Osirian chapel in the temple of Dendera; there, however, it is standing, its legs slightly bent, also with a ram's head and with a reed knife/leaf in its right hand. ${ }^{64}$

$5^{\text {th }}$ figure: $\bar{Q}$

The fifth demon has a human head and is squatting with a gazelle in its hands. It bears the name $S m t,{ }^{65}$ also attested in Book of the Dead Spells 144 and 147, where it designates the guardian of the first gate: Smty, "the eavesdropper, hearer" ${ }^{66}$ It is also found in the tomb of Ramesses III (KV 11) $)^{67}$ and in the third eastern Osiris chapel in the temple of Dendera, in both cases represented as a standing man with slightly bent legs holding up a gazelle in its hands; its caption here reads $S m t j n b$ "the one who hears the lord" ${ }^{68}$ On the Turin fragments, this entity is given a further designation: 3 smt "the one great of hearing/ the one with acute hearing".

$6^{\text {th }}$ figure:

Based on parallels, the sixth demon was presumably an upright standing baboon. In some of these parallels, it is depicted with a bow in its hands; ${ }^{69}$ however, all its occurrences in the canonised versions on coffins and sarcophagi lack this feature. Its name is commonly read as $J f w .{ }^{70}$ What is presumably its tail is still preserved on the following fragment. The upright standing baboon that is slightly bent forward is also attested in the temple of Hibis, in the second register of the north wall of the sanctuary. There, enough of the inscription is left to identify it as $J f w$, too. ${ }^{71}$ This depiction is followed by a baboon sitting on a box or shrine, but the preserved hieroglyphs, which read $b n n[. .],.{ }^{72}$ suggest that it is not identical with the two baboons sitting on a shrine that usu- 
ally follow $J f w$ in this sequence of apotropaic gods. The god $J f w$ is further attested in the row of apotropaic entities in the third eastern Osirian chapel in the temple of Dendera, also portrayed as an upright standing baboon, but this time with its hands raised in adoration. ${ }^{73}$

Excerpt of Book of the Dead Spell 168 between figures 6 and 7 :

The following text has a close parallel in a section of Book of the Dead Spell 168, the so-called "Grüftebuch". Actually this is not part of the original Book of the Dead manuscripts, but an independent composition, more specifically a litany of offerings to divinities of different caverns. ${ }^{74}$ According to Lucarelli, and others before her, it rather belongs to the category of "Guides of the Netherworld" ${ }^{75}$ The passage on the Turin fragments reads as follows:
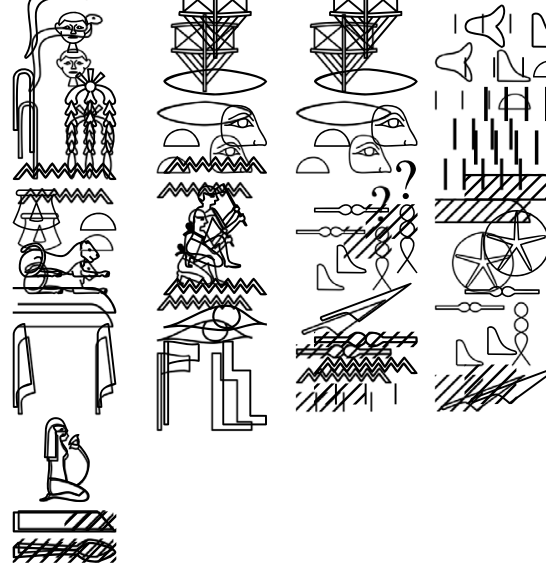

$[n \underline{t} r]^{1} . w k r(r) . w t 9 m d 3 . t h s k^{2} \underline{t} 3 w r$ fnd $\underline{d}(?)^{76} h s k=s n^{3} \underline{t} 3 w$ $r$ fnd $n$ hftj $n$ Wsjr ${ }^{4} \underline{D} d-h r$ msj.n Tglmy m m${ }^{e}(. t)-h r w$

"[The god] ${ }^{1} \mathrm{~s}$ of the nine caverns ${ }^{77}$ in the underworld, who cut off ${ }^{2}$ the air from the nose (?). They cut off ${ }^{3}$ the air from the nose of the enemy of the Osiris ${ }^{4}$ of Djedher, whom Teglemy justified has born."

The corresponding parallel passage in Book of the Dead Spell 168 needs to be understood as a "Beischrift" to the list that follows. In P. BM EA 10478, for instance, it is written in red ink and reads: $n \underline{t} r . w$

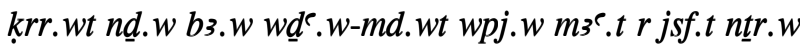
krr.wt psd.t $m$ d3.t št3.t jrj.w hsk țww "the gods of the caverns, who protect the bas, who judge, who distinguish truth from falsehood, gods of the caverns, the Ennead in the secret underworld, who cut off the air". Furthermore, it can be found again later in that spell as the description of the $9^{\text {th }}$ cavern: ntr.w krr.t 8.nwt (sic) $m$ d3.t štz.t jrj.w hssk $\{k\} \underline{t} \leq 3 w$ "the gods of the $\{$ eighth $\}<$ ninth $>$ cavern in the secret underworld, who cut off the air". ${ }^{78}$

Since the three plural strokes - most likely belonging to $n t r . w$ - are the first signs preserved in the first column of the Turin papyrus fragments, it is not certain how much of Book of the Dead Spell 168 was excerpted, more specifically, whether it started with $n \underline{t} r . w$ or whether, for instance, $n \underline{t} r . w$ krr.wt $n \underline{d} . w$ $b_{3} . w w d{ }^{r} . w-m d . w t w p j . w ~ m 3^{r} . t r j s f . t$, i.e. the name of the eighth cavern, ${ }^{79}$ was written before it. However, since clear traces of the standing baboon are preserved right in front of the first text column, it can be assumed that this text passage was not written before the first preserved text column, but probably originally at the beginning of the row of protective entities, and maybe the scribe had already started to write $n t r . w$ accidentally there.

It is also interesting that the passage from Book of the Dead Spell 168 seems to have been repeated twice here, but slightly differently each time, first as an epithet of the gods, and then as a caption specifying their task as those who act against the enemies of Djedher, the deceased. In Book of the Dead Spell 168 , this passage is used solely as an epithet of the relevant divinities.

The figures of Book of the Dead Spell 168 can also be found in the soubassement of the third eastern Osiris chapel in Dendera, where some of the entities encountered on the Turin fragments are featured as well. $^{80}$

$7^{\text {th }}$ and $8^{\text {th }}$ figure:

The following demon-group consists of two baboons sitting on a shrine. The first bears the name Shd- $h r .{ }^{81}$ The name of the second baboon, usually $D b-h r=k,{ }^{82}$ is not written. The names of these two baboons are short forms of names that are also attested in Book of the Dead Spells 144 and 147. The doorkeeper of the first gate is designated as Shd$h r$ “̌̌s-jrw "face downward, numerous of shapes", and the announcer of the fifth gate as $D b-h r k h_{3}-3 t$ "hippopotamus-faced, violent of strength" in both spells. ${ }^{83}$ The two baboons, each sitting on a podium, are also attested in a row of protective beings in the third eastern Osiris chapel in the temple of Dendera, 
where they are designated as $S h d-h r$ and $D b-h r^{.84}$ The group of the three baboons - one standing, two sitting - can likewise be found in the tomb of Ramesses III (KV 11) and in some tombs in the Valley of the Queens. ${ }^{85}$

$9^{\text {th }}$ figure:

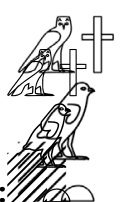

The name of the following demon, $J m y-w t,{ }^{86}$ is written immediately after the second squatting baboon. In parallels, this deity has a jackal head and a snake in its hands. However, nothing of its depiction survives on the papyrus fragments in the Museo Egizio, except for some traces of ink below the name that originally might have belonged to the head of the snake.

$10^{\text {th }}$ and $11^{\text {th }}$ figure:

A further fragment is preserved which continues the row of protective entities. Still visible is the lower half of the body of the $11^{\text {th }}$ figure, as well as the bottom part of the snake it is holding and that of the serpent held by the preceding divinity. In parallels, this demon is ram-headed, holds a snake in its left hand, and is called $\mathrm{Hnf}_{3} .^{87}$ The preceding demon has the head of a crocodile, holds a snake with both hands, and is called $D w n-h 3 . t .^{88}$

Possible continuation of the figures:

The row of protective figures breaks off at this point on the fragments in the Museo Egizio. Nevertheless, based on the coffin and sarcophagus attestations discussed above, the four sons of Horus would have followed in an unusual guise, with Amset and Hapy in human-headed form holding a lizard in each hand, the jackal-headed Duamutef holding a snake with both hands, and the human-headed Qebehsenuef with two crossed snakes in his hands.

While the examples from coffins and sarcophagi listed above display the same arrangement of protective figures and in most cases also with their names inscribed above their heads as on the Turin fragments, the extended version of the passage from Book of the Dead Spell 168 inserted into the decoration on the papyrus is attested neither on the coffins nor on the sarcophagi.

\subsection{Role and meaning of the "outer cir- cle" and the protective entities on the Turin fragments}

According to Assmann, the group of deities to which the ones on the Turin fragments belong can be connected to the embalming and burial of the corpse of Osiris, and is associated with the Osirian nightly vigil, the "Stundenwachen" in the embalming hall. ${ }^{89}$ In the tomb of Mutirdis (TT 410), where the protective entities are depicted on the east and west walls, we find the so-called Awakening Scene on the south wall, showing Horus holding an ' $n h$-sign and a wsssign to the face of his father, thus awakening Osiris who is lying on his bed. ${ }^{90}$ The placement of the sarcophagus in the middle surrounded by the figures is thus the realisation of the Awakening Scene and the demons hence relate to the sarcophagus in the same way as they do to the scene of the awakened Osiris depicted on the wall. ${ }^{91}$ Whether as wooden or stone figurines in the burial chamber around the sarcophagus or as figures depicted around the body of the coffin, these images serve the same function of creating a protective circle in order to ward off any evil from the body of the deceased. We can therefore assume with some certainty that the demons on the papyrus from the Museo Egizio originally encircled the whole of what was written and drawn in the inner section, and hence also provided a guarding ring, in exactly the same way as the statuettes and depictions on tomb walls and coffins. ${ }^{92}$

\section{Annotations}

A further peculiarity of these papyrus fragments is the insertion or correction mark visible below the fourth preserved demon, designated as Sm.t. The lighter grey colour of the ink as well as the use of a thicker rush stem suggests that this mark was not added simultaneously with the drawing of the original composition. It may have been inserted later, during a revision of the finished manuscript. The sign is the writing of the Demotic ty, "here". ${ }^{93}$ It is also used, for instance, in the Leiden manuscript of the Myth of the Sun's Eye, where this group marks the position for words that need to be added. ${ }^{94}$ Since the Turin fragment breaks off immediately after the mark, it is impossible to say anything about the original content of the corresponding gloss, which was 


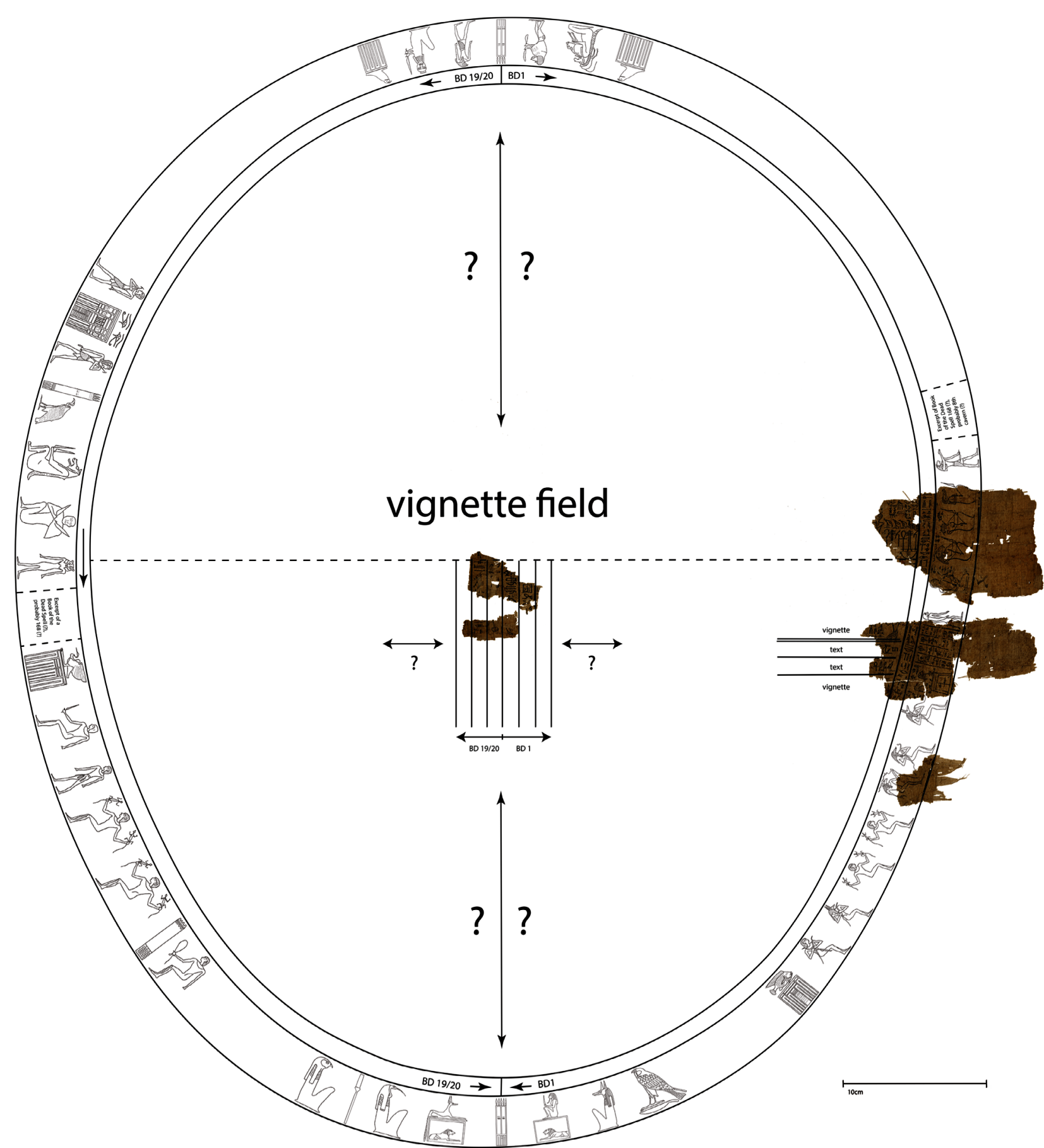

Fig. 2: Proposed reconstruction of P. Turin Provv. 6133. (The reconstruction of the demons in the "outer circle" is based on those of the sarcophagus of Psusennes I [see the literature references in n. 23]).

probably written in the upper or lower margin of the papyrus. Nevertheless, as the name of the protective deity to which it seems to have been attributed is written in an unusually elaborate version, the gloss may have provided clarification on this.

\section{Content and nature of the papyrus frag- ments and provisional reconstruction}

I provide here a provisional reconstruction (Fig. 2) based on the above investigation. I have placed the preserved fragments in a more or less circular or oval format following the curve of the lines. I am aware of the fact that the curved lines at the top and the bottom might also have been flattened, for instance. ${ }^{95}$ Unfortunately, it is impossible to specify the exact form of the head and the foot ends due to lack of papyrus fragments from these areas. The figures in the "outer circle" belong to a group of protective entities concerned with the protection of Osiris, and thus of the deceased, which is known to us in this canonised form. This series can be reconstructed with some certainty. An interesting phenomenon 


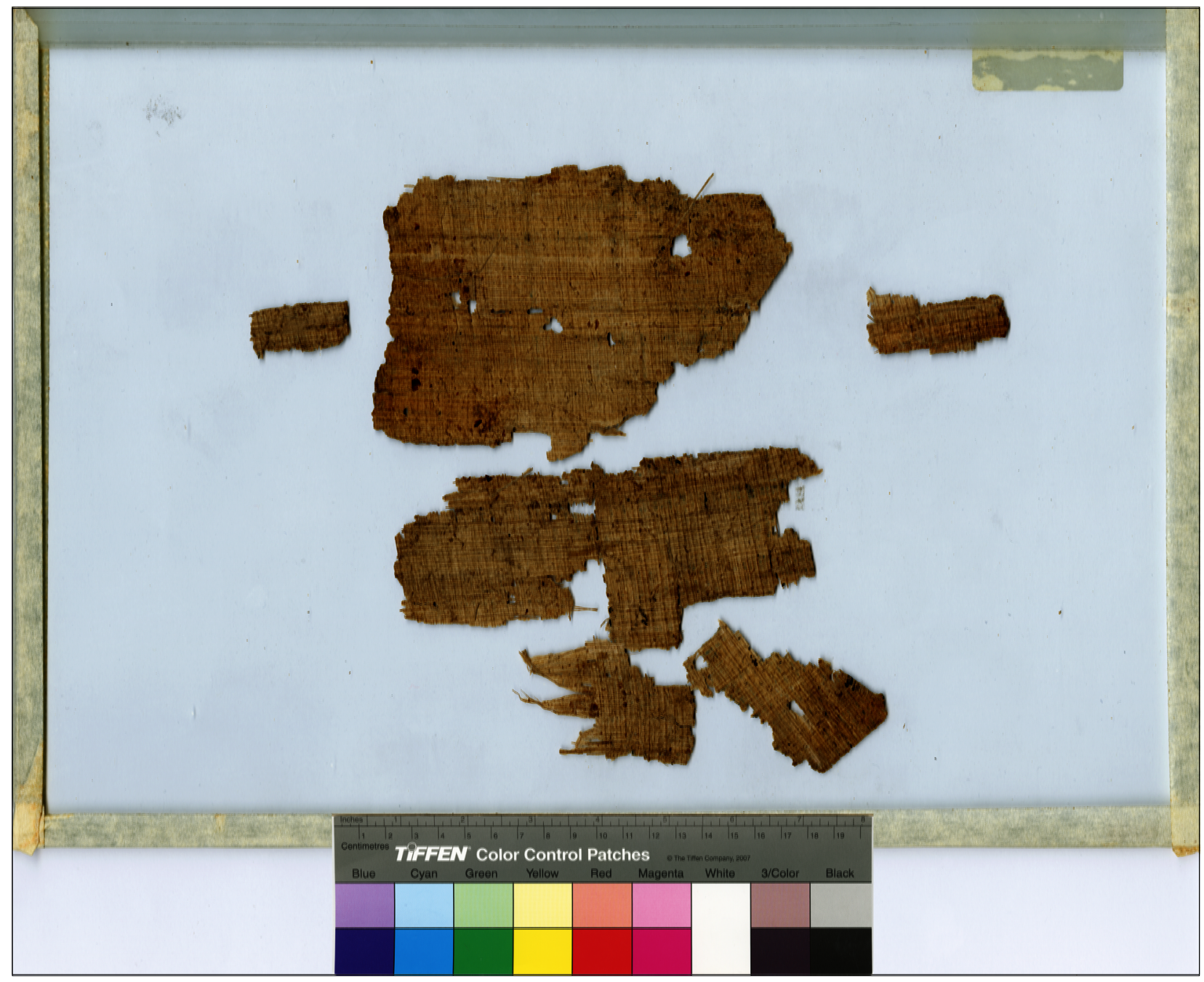

Fig. 3: Verso of P. Turin Provv. 6133 as currently mounted. Scan by Museo Egizio.

observable in attestations of these protective entities is that they clearly follow a specific order when they are depicted in groups. Moreover, these beings or groups thereof seem to be assigned most of the time to specific cardinal points (compare the list of coffins and sarcophagi above). The specific category of demons in the particular order that is also preserved on the Museo Egizio fragments is mostly situated on the left side of the coffin. In the Turin papyrus, they appear in the same position, on the right side of the composition, which corresponds to the (proper) left side of the coffin.

Furthermore, the group of demons has a specific counterpart, which is usually placed on the opposite side. It is therefore justified to assume that this group was originally drawn on the left side of the "outer circle". It is not possible to say, instead, whether an excerpt of Book of the Dead Spell 168 or another similar spell was likewise inserted among the figures of this group. The space at the "head" and "foot" ends of the "outer circle" could originally have been decorated with demons found in the corresponding position on parallels, such as, for instance, those preserved on the short sides of the sarcophagus of Psusennes I. ${ }^{96}$

My placement of the two fragments in the middle of the oval is based on several factors: the orientation of the hieroglyphs; a tiny but certain section of a vignette at the top of the upper fragment; and the rather prominent horizontal fibres on the verso of the lower fragment, which match those on the verso of the central fragment on the right side of the reconstruction (Fig. 3).

The length of the columns can be estimated with the help of the above-mentioned parallels. As Book of the Dead Spell 1 started in the single text column on the right and continued in the right half of the inner section, I would propose that Book of the Dead Spell 19 or 20 , which occupies the left side of the inner section, likewise started in the single text column, in 
this case in the left half of the oval, and then continued in the columns of text on the left in the middle section. As already pointed out, above this inner text field we find a vignette field that perhaps extended horizontally all the way to the single text columns on either side. The lower separation line of this vignette, which is still preserved on the right side, would thus have been at the same level as that of the vignette in the centre of the composition.

Although these pieces have previously been ascribed to a hypocephalus, most likely based on the curved outer lines, the new reconstruction highlights that the bend of the lines is not congruent with an exact circle. Furthermore, none of the typical vignettes or texts found on hypocephali, such as Book of the Dead Spell 162, are found on the Museo Egizio fragments. Based on this unusual form as well as the presence of the canonised group of protective entities only at-

\section{Notes}

${ }^{1}$ After joining, five major fragments remain; compare the reconstruction at the end of this article.

${ }^{2}$ I would like to thank Susanne Töpfer for drawing my attention to these fragments, and Carolina Teotino for her advice and information on the entourage of Osiris. I am indebted to Manon Schutz for supplying me with copies of articles and books I could not consult in Turin, to Martina Landrino for technical advice, and to Arto Belekdanian and Federico Poole for proofreading the English. I owe a debt of gratitude to Mark Smith, Holger Kockelmann, Manon Schutz, Thomas Christiansen, Federico Poole, Carolina Teotino, Susanne Töpfer, and the anonymous reviewers for their corrections and suggestions.

${ }^{3}$ For the combination of these animals in a magical context, however, in varying numbers, compare, for instance, the vignettes on P. Bibl. Nat. Paris 177: http://gallica.bnf.fr/ark:/12148/btv1b8304603c/ fl.zoom.r=phylact (last accessed on 19.04.2018).

${ }^{4}$ I would like to thank Thomas Christiansen for this suggestion.

${ }^{5}$ For birds as symbols of protection in ancient Egypt, compare, for instance, Shonkwiler, in Bailleul-LeSuer (ed.), Between Heaven and Earth, 2012, pp. 49-57 with further literature.

${ }^{6}$ In addition to the walking legs-sign, the still preserved traces of ink may belong to the tail feathers of the $k$ bird.

${ }^{7}$ I would like to thank Susanne Töpfer for this suggestion.

${ }^{8}$ The reading of this section is not entirely clear. One can see that the top sections of the two signs do not look exactly the same, which might be a slip of the tested in this specific arrangement on a number of coffins and sarcophagi, I would like to suggest two alternative interpretations for the Turin papyrus. First, it seems fitting to consider our arrangement either as a copy of, or a template for, a coffin or sarcophagus, i.e. that of Djedher, son of Teglemy. The Demotic correction mark that was added later could be the result of a subsequent amendment to the original template, before the practical execution of the object. However, I am aware of no other example of such a "coffin template papyrus".

A second possibility would be that the papyrus was placed on top of the mummy in its coffin. ${ }^{97}$ The Book of the Dead spells as well as the outer circle of protective figures would thus have had the same purpose as the one they would have had had they been carved or painted on the coffin itself: the all-encircling protection of the deceased.

pen. Nevertheless, this would seem rather unlikely, as the top of the left sign clearly has two small strokes attached at an angle to the vertical one, and the sign on the right has a continuous horizontal stroke with a little black dot in the middle. Although I could not find any other hieratic or cursive hieroglyphic parallels, the two signs might read 8 , so that the epithet or divine designation would be $n b . w / n b . w t s ̌ m s . w ~ m h . w / t 3 . w j$ "the lords/ladies of Upper and Lower Egypt/the Two Lands"; compare $L G G$, III, 2002, 821c for attestations of $n b . w \check{s} m^{`} . w$ mh.w. I would like to thank Carolina Teotino for pointing out to me that the little circles are to be understood as the town-sign, and that the two signs could also be However, if we assume that the different appearance of the signs is due to a slip of the pen, and that the same sign is actually written twice, then the reading could be sn.tj "the two sisters" or "the two $s n w$-serpents". The $s n w$-serpent is attested as a poisonous animal on the magical statue of Djedher (JE 46341); see Jelínková-Reymond, Djed-Herle-Sauveur, 1956, pp. 29 and 34 (1.66) and compare also $L G G$, VI, 2002, 378c.

${ }^{9}$ Some of the versions of Book of the Dead Spell 1 add the adverb jm; compare the synopsis by Lüscher, Totenbuch Spruch 1, 1986, p. 17.

${ }^{10}$ Reconstruction according to P. Turin Cat.1791; compare the pictures in Totenbuchprojekt Bonn, TM 57201, totenbuch.awk.nrw.de/objekt/tm57201 (last accessed on 26.04.2018). See also the synopsis in Lüscher, Totenbuch Spruch 1, 1986, pp. 16-18.

${ }^{11}$ See PN, I, 1935, p. 411.

12 The name Tgrmy/Tglmy is only rarely attested; compare PN, I, 1935, p. 371 (under t3-grmj [?]) and Kockelmann, 
Totenbuch-Handschriften, II, 2008, p. 263, n. 126.

${ }^{13}$ Reconstruction based on P. Turin Cat.1791; compare the pictures in The Database of the Book of the Dead project: Totenbuchprojekt Bonn, TM 57201, totenbuch. awk.nrw.de/objekt/tm57201 (last accessed on 26.04.2018).

${ }^{14}$ For a detailed study of these three Book of the Dead spells and Spell 18 in particular, see Végh, in Bickel et al. (eds.), Ancient Egyptian Funerary Literature, 2017, pp. 513-52.

${ }^{15}$ For further information and different versions of Book of the Dead Spell 18, see Végh, in Bickel et al. (eds.), Ancient Egyptian Funerary Literature, 2017, and Lapp, Totenbuch Sprüche 18, 20, 2009, more specifically pp. $35 \mathrm{~b}-45 \mathrm{a}$ (Spruch 18c-d) for the relevant passage and compare also the entries in the Totenbuchprojekt Bonn database, http://totenbuch.awk.nrw.de/spruch/18 (last accessed on 27.04.2018). For further information on the First Letter of Breathing, see Herbin, Books of Breathing, 2008, with pp. 50-51 and the commentary on p. 59 for our specific passage.

${ }^{16}$ The reconstruction of both spells is based on P. Turin Cat.1791; compare the pictures in Totenbuchprojekt Bonn, TM 57201, totenbuch.awk.nrw.de/objekt/ tm57201 (last accessed on 26.04.2018).

${ }^{17}$ Compare, for instance, the synopsis by Lapp, Totenbuch Sprüche 18, 20, 2009, p. 151 for the section that is also present in the Turin fragments.

${ }^{18}$ For a general discussion of these demon guards in the Book of the Dead, see the investigation by Lucarelli, in BMSAES 5 (2010), pp. 85-102, with further literature. Compare also Lucarelli, in Morenz et al. (eds.), Weitergabe, 2015, pp. 275-91 and Lucarelli, in Lucarelli et al. (eds.), Herausgehen am Tage, 2012, p. 86.

${ }^{19}$ Compare the detailed discussion by Lucarelli, in Lucarelli et al. (eds.), Herausgehen am Tage, 2012, pp. 79-91. As Lucarelli (in Lucarelli et al. [eds.], Herausgehen am Tage, 2012, pp. 89-90) has pointed out, the vignette is rather connected to Book of the Dead Spell 151 which follows after it.

${ }^{20}$ Personal communication (24.03.2018); see also Teotino, in Dawson and Strudwick (eds.), Ancient Egyptian Coffins, forthcoming. She is currently preparing her PhD thesis entitled "Die apotropäischen Gottheiten des Osiris: Eine Studie zu den

Schutzgöttern nach Quellen der Spät- und griechischrömischen Zeit" (University of Tübingen) on the apotropaic entourage of Osiris.

${ }^{21}$ The following list is an extended version of that provided by Leclant, in Pigulevskaja (ed.), Fs Struve, 1962, pp. 106-09. A compilation of some of the demon friezes on the sides of the coffins and sarcophagi was also undertaken by Sist, in Baglioni (ed.), Monstra, I, 2013, pp. 77-78.

22 Seen from the mummy's perspective.

${ }^{23}$ Compare the publication in Montet, Tanis, II, 1951, pp. 115-17 and pls. LXXXII-LXXXIX. See also Leclant, in Pigulevskaja (ed.), Fs Struve, 1962, p. 106, with fig. 14 on p. 107, and Teotino, in Dawson and Strudwick (eds.), Ancient Egyptian Coffins, forthcoming.

${ }^{24}$ Compare the photographs and the information in Taylor, Journey Through the Afterlife, 2010, pp. 202-03 and Schmidt, Sarkofager, 1919, pp. 194-95, figs. 1094-1102. Also mentioned by Leclant, in Pigulevskaja (ed.), Fs Struve, 1962, p. 108 and Teotino, in Dawson and Strudwick (eds.), Ancient Egyptian Coffins, forthcoming.

${ }^{25}$ The coffin is still unpublished. Compare the photographs and information in the British Museum's online collection: https://www.britishmuseum. org/collection/object/Y_EA30721 (last accessed on 09.12.2020). Also mentioned by Teotino, in Dawson and Strudwick (eds.), Ancient Egyptian Coffins, forthcoming.

${ }^{26}$ Sist, in Amadasi Guzzo et al. (eds.), Da Pyrgi a Mozia, 2002, pp. 533-45; Sist, in Baglioni (ed.), Monstra, I, 2013, pp. 73-83, and Sist, in Amenta et al. (eds.), Proceedings First Vatican Coffin Conference, 2017, pp. 509-16.

${ }^{27}$ Compare the photographs and information by Moret, Sarcophages de l'époque bubastite à l'époque saïte, 1913, pp. 24-27 and pl. III and Schmidt, Sarkofager, 1919, p. 181, fig. 1006. See also Leclant, in Pigulevskaja (ed.), Fs Struve, 1962, p. 108, with fig. 16 on p. 110, and Teotino, in Dawson and Strudwick (eds.), Ancient Egyptian Coffins, forthcoming.

${ }^{28}$ Leclant, in Pigulevskaja (ed.), Fs Struve, 1962, p. 108, fig. 17 on p. 111, and fig. 18 on p. 113. Compare also Jansen-Winkeln, Inschriften der Spätzeit, IV. Die 26. Dynastie, I, 2014, pp. 479-82 and the literature references cited there (reference courtesy of Carolina Teotino).

${ }^{29}$ Daressy, ASAE 17 (1917), pp. 5-11. See also Leclant, in Pigulevskaja (ed.), Fs Struve, 1962, p. 108 and Teotino, in Dawson and Strudwick (eds.), Ancient Egyptian Coffins, forthcoming.

${ }^{30}$ Maspero, Sarcophages des époques persane et ptolémaïque, I, 1914, pp. 42-43, 52-53, pls. IV-V. See also Leclant, in Pigulevskaja (ed.), Fs Struve, 1962, p. 108 and fig. 19 on p. 115.

${ }^{31}$ Maspero, Sarcophages des époques persane et ptolémä̈que, I, 1914, pp. 86-114 with pls. IX-XIII, and more specifically p. 106 and pl. XII. See also Leclant, in Pigulevskaja (ed.), Fs Struve, 1962, p. 108, with fig. 20 on p. 115 and Teotino, in Dawson and Strudwick (eds.), Ancient Egyptian Coffins, forthcoming.

${ }^{32}$ Maspero, Sarcophages des époques persane et ptolémaïque, I, 1914, pp. 130-33, 137-43, and pls. XVII-XVIII. See also Leclant, in Pigulevskaja (ed.), Fs Struve, 1962, p. 109 and Teotino, in Dawson and Strudwick (eds.), Ancient Egyptian Coffins, forthcoming.

${ }^{33}$ Maspero and Gauthier, Sarcophages des époques persane et ptolémaïque, II, 1939, pp. 51-52, 54-55, with pls. XIII-XV.

${ }^{34}$ However, as Waitkus, GM 99 (1987), p. 68, pointed out, the dating of the sarcophagus decoration is not unproblematic. While it is certain that the sarcophagus lid was first made for Merenptah and then reused by Psusennes, due to the fact that it was reworked, it is uncertain whether the same applies to the box of the sarcophagus and at what point it was decorated. It seems more likely to me that at least the decoration of the box was added in the time 
of Psusennes I and thus dates to the Twenty-first Dynasty. Nevertheless, even in this case this would be the earliest attestation of the canonised form of these protective entities.

${ }^{35}$ Montet, Tanis, I, 1947, p. 60 and pl. LI. See also Leclant, in Pigulevskaja (ed.), Fs Struve, 1962, p. 108.

${ }^{36}$ The publication of this coffin is currently in preparation by Carolina Teotino (University of Tübingen). For up-to-date information and general pictures, see http://www.globalegyptianmuseum.org/ detail.aspx?id=1177 (last accessed on 18.03.2018); Vanlathem, Oudegyptische lijkkisten en mummies, 1983, pp. 22-23, and Delvaux and Therasse (eds.), Sarcophages, 2015, pp. 144-47.

${ }^{37}$ Leitz, Der Sarg des Panehemisis in Wien, 2011. See also Teotino, in Dawson and Strudwick (eds.), Ancient Egyptian Coffins, forthcoming.

${ }^{38}$ Leitz, Der Sarg des Panehemisis in Wien, 2011. See also Teotino, in Dawson and Strudwick (eds.), Ancient Egyptian Coffins, forthcoming.

${ }^{39}$ Leemans, Aegyptische Monumenten, I/7, 1845, pls. XXXVIb, c, e; Boeser, Beschrijving, VII, 1914, p. 1, pls. I-V; Schneider and Raven, De Egyptische oudheid, 1981, no. 123, and Schneider, Beeldhouwkunst in het land van de farao's, 1992, pp. 80-82, no. 33. Compare also the pictures on http://www.globalegyptianmuseum.org/ record.aspx?id=13997 (last accessed on 18.03.2018).

${ }^{40}$ Dendara, X, 1997, pp. 194-98 and pls. 94-95 and Cauville, Chapelles osiriennes, II: Commentaire, 1997, pp. 90-95. Individual attestations of the Turin beings are mentioned below in the specific investigation of the "outer circle".

${ }^{41}$ See the lists provided by Altenmüller, LÄ II (1977), col. 639, n. 23 and 24.

${ }^{42}$ For a list of tombs in the Queens' Valley and an investigation of the apotropaic deities that appear there and in the tomb of Ramesses III, see Waitkus, GM 99 (1987), pp. 51-82. Compare also Teotino, in Dawson and Strudwick (eds.), Ancient Egyptian Coffins, forthcoming.

${ }^{43}$ Montet, Tanis, II, 1951, pl. XIV and Goyon, La découverte des trésors de Tanis, 1987, p. 111.

${ }^{44}$ Compare the publication and description by Assmann, Das Grab der Mutirdis, 1977, p. 94 and pls. 43 and 45.

${ }^{45}$ Assmann, Das Grab der Mutirdis, 1977, p. 94.

${ }^{46}$ See Taylor, Journey Through the Afterlife, 2010, pp. 200-01; Wilkinson and Reeves, The Complete Valley of the Kings, 1996, pp. 132-35 and 169; Lucarelli, in Lucarelli et al. (eds.), Herausgehen am Tage, 2012, pp. 87-88; Lucarelli, BMSAES 15 (2010), p. 90, with fig. 9, and Waitkus, GM 99 (1987), p. 65 with further literature and a list of statues from royal tombs of the New Kingdom on pp. 81-82. For the statuettes now in the British Museum, see also the online collection http://www. britishmuseum.org/research/collection_online/ collection_object_details/collection_image_gallery. aspx? partid $=1 \&$ assetid $=315310001 \&$ objectid $=156250$ and http://www.britishmuseum.org/ research/collection_online/collection object_details/collection_image_gallery. aspx? partid $=1$ \&assetid $=315324001 \&$ objectid $=156252$ (last accessed on 05.04.2018).

${ }^{47}$ Compare Gill, The Hieratic Ritual Books of Pawerem, 2016, pp. 263-64. These figures were most likely covered with $3 . t-n t r$, a black substance that was used for coating statues. Compare Töpfer, Balsamierungsritual, 2015, p. 146 for more information on 3.t-ntr (reference courtesy of anonymous reviewer).

${ }^{48}$ Compare their publication by Leclant, in Pigulevskaja (ed.), Fs Struve, 1962, pp. 104-29; Leclant, Montouemhat, 1961, pp. 113-32, with pls. XXXIV-XLII; Clère, BIFAO 86 (1986), pp. 99-106, and Eigner, Grabbauten der Spätzeit, 1984, pp. $44-46,136,141-44$. The statuettes of that group from the tomb of Montuemhat will be discussed in detail in Gestermann, Louise, Carolina Teotino and Mareike Wagner, Zum Dekorationsprogramm in der spätzeitlichen Grabanlage des Monthemhet, in preparation. I would like to thank Carolina Teotino for this information.

${ }^{49}$ Compare the drawing by Sist, in Amenta et al. (eds.), Proceedings First Vatican Coffin Conference, 2017, p. 513, fig. 6 for the proposed original arrangement of these figurines in the tomb of Montuemhat.

${ }^{50}$ Montet, Tanis, II, 1951, pls. LXXXII-LXXXV.

${ }^{51}$ Compare Assmann, Das Grab der Mutirdis, 1977, p. 93 for this designation and see also Waitkus, GM 99 (1987), p. 72, n. 110 for more information on this way of depicting these specific figures.

${ }^{52}$ Taylor, Journey Through the Afterlife, 2010, pp. 202-03 and Teotino, in Dawson et al. (eds.), Ancient Egyptian Coffins, forthcoming.

${ }^{53}$ Assmann, Totenliturgien, I, 2002, p. 242. See also Lucarelli, in Lucarelli et al. (eds.), Herausgehen am Tage, 2012, p. 87, with n. 45 for mentions of the m3s.w/ msstj.w "the kneeling/squatting ones" in the Coffin Texts and their related representation on coffins. For the "kneeling ones" as the gatekeepers of the abode of Osiris in the Coffin Texts, see Sherbiny, Through Hermopolitan Lenses, 2017, pp. 212-13, 329, and 342-43.

${ }^{54}$ Coffin Text Spell 1079 (CT VII, 1961, p. 351b-f). See also the translation by Assmann, Totenliturgien, I, 2002, p. 242.

${ }^{55}$ This reconstruction is based on parallel depictions discussed above.

${ }^{56}$ LGG, V, 2002, 955b: “der am Anfang abwehrt”. A translation "who wards off from the presence (scil. of Osiris)" seems to be preferable (reference courtesy of Mark Smith).

${ }^{57}$ Compare the literature references under n. 39.

${ }^{58}$ For more information on this entity, see Teotino, in Dawson and Strudwick (eds.), Ancient Egyptian Coffins, forthcoming. For its attestation in the Book of the Dead, see Lucarelli, BMSAES 15 (2010), p. 93 and compare also Waitkus, GM 99 (1987), pp. 55-56. It is depicted in the same way in the third eastern Osiris chapel in the temple of Dendera, in a row of protective entities in the soubassement; see Dendara, X, 1997, p. 197 and pl. 95 (no. 34). Although it is no longer preserved in the Turin fragments, it can be assumed that this figure headed our group, as it does in the 
parallels. $R s-j b$ is, therefore, regarded as the " $1^{\text {st }}$ figure" in the following numbering.

${ }^{59}$ LGG, II, 2002, 408a: "der das Verfaulte frisst". Note the writing of $h w 33 . t$ with $O$ probably as an ideogram. For $w n m-h w 33 . t$, see the discussion by Pantalacci, BIFAO 83 (1983), pp. 297-311.

${ }^{60}$ See, for instance, Lucarelli, BMSAES 15 (2010), p. 87 for a short summary of the main features of these spells.

${ }^{61}$ See Allen, Book of the Dead, 1974, 144 b § P 2; 147 c § P 1, and p. 288 and Lucarelli, BMSAES 15 (2010), p. 93.

${ }^{62}$ Dendara, X, 1997, p. 197 and pl. 95 (no. 33).

${ }^{63} L G G$, IV, 2002, 212b: "der mit vollkommener Vollkommenheit".

${ }^{64}$ Dendara, X, 1997, p. 195 and pl. 94 (no. 32).

${ }^{65}$ LGG, VI, 2002, 358a and Lucarelli, BMSAES 15 (2010), p. 89. For this entity, compare also Leitz, Der Sarg des Panehemisis in Wien, 2011, pp. 144-45.

${ }^{66}$ See Allen, Book of the Dead, 1974, 144 b § P 2; 147 a § P 1, and p. 301 and compare Lucarelli, BMSAES 15 (2010), p. 93.

${ }^{67}$ Compare Waitkus, GM 99 (1987), p. 63 for more details.

${ }^{68}$ Dendara, X, 1997, p. 197 and pl. 95 (no. 32). See $L G G$, VI, 2002, 358c and Cauville, Chapelles osiriennes, II. Commentaire, 1997, p. 92.

${ }^{69}$ Compare, for instance, the examples cited by Waitkus, GM 99 (1987), pp. 53-54.

${ }^{70}$ LGG, I, 2002, 222b: “der zujubelt (?)”.

${ }^{71}$ Davies, Hibis, III, 1953, pl. 3.

${ }^{72}$ It is probably identical with the mummy with baboonhead called Bnny in the Amduat; see LGG, II, 2002, 802 a.

${ }^{73}$ Dendara, X, 1997, p. 195 and pl. 94 (no. 31).

${ }^{74}$ First made clear by Piankoff, Wandering of the Soul, 1974, p. 42. See also Müller-Roth and Weber, GM 226 (2010), p. 65, and compare von Lieven, JEA 98 (2012), p. 253 , with further literature.

${ }^{75}$ Lucarelli, in Lucarelli et al. (eds.), Herausgehen am Tage, 2012, p. 82, n. 17; Quack, WdO 28 (1997), p. 180 (reference courtesy of anonymous reviewer).

${ }^{76}$ There are traces of ink of a sign that follows after fnd . It seems as if the scribe started to write something but then stopped. Perhaps he wrote the hftj-sign as in the next column, but did not finish it.

${ }^{77}$ In the light of a comparison with the parallels for this passage in Book of the Dead Spell 168, it seems that there are different options for translating the nine little strokes. In the introductory "Beischrift", the parallel says "Ennead", and later on says "ninth cavern" for the relevant cavern; the writing here with only nine strokes would, however, also allow the reading "nine caverns", while "Ennead" seems to be rather unlikely due to the lack of any divine determinative and since the writing for $p s$ d.t is usually different.

${ }^{78}$ Piankoff, Wandering of the Soul, 1974, pp. 45-46, 48 with n. 33 and pl. 17 and 21. Compare also the photographs on Totenbuchprojekt Bonn, TM 134513, totenbuch.awk.nrw.de/objekt/tm134513 (last accessed on 06.04.2018), and see the rubrum in P. Cairo CG 24742 (Piankoff, Wandering of the Soul, 1974, pl. 10).

${ }^{79}$ See Piankoff, Wandering of the Soul, 1974, p. 45, with n. 28.

${ }^{80}$ Compare the remarks by von Lieven, JEA 98 (2012), p. 253 (reference courtesy of Carolina Teotino).

${ }^{81} L G G$, VI, 2002, 592b.

${ }^{82}$ LGG, VII, 2002, 528c.

${ }^{83}$ Based on the papyrus of $\mathrm{Nu}$ (P. BM EA 10477) for Spell 144 and on the papyrus of Ani (P. BM EA 10470) for Spell 147; see Lapp, Nu, 1996, pl. 74 and Allen, Book of the Dead, 1974, 144 b § P 2 and 147 a § P 1 for shd-hr, and $144 \mathrm{~b} \S \mathrm{P} 2$ and 147 e $\S \mathrm{P} 1$ for $d b-h r$, and compare p. 302 and 305. See also Lucarelli, BMSAES 15 (2010), p. 93. The form $d b-h r=k$ might be connected to $d b h r$ $k h_{3} 3 t$ and could be an abbreviated form of it; compare LGG, VII, 2002, 528c.

${ }^{84}$ Dendara, X, 1997, p. 197 and pl. 95 (nos. 30 and 31). A list of other occurrences of the standing baboon and the two seated ones as guardians, particularly of Osiris, for instance, in Book of the Dead vignettes, is provided by Waitkus, GM 99 (1987), p. 54, n. 24.

${ }^{85}$ Compare Waitkus, GM 99 (1987), pp. 53-54 for more details and a list of tombs.

${ }^{86}$ LGG, I, 2002, 232c: "der in der Balsamierungsstätte ist”.

${ }^{87}$ LGG, V, 2002, 751b: “der Behaarte (?)”. For its attestation in the tomb of Ramesses III (KV 11), see Waitkus, GM 99 (1987), pp. 60-61. For more information, especially on the possible meaning of this name, see Roberson, Awakening of Osiris, 2013, pp. 33-34.

${ }^{88}$ LGG, VII, 2002, 526c: "der mit ausgestreckter Stirn”. Compare Lucarelli, BMSAES 15 (2010), p. 93 for attestations of this demon in the Book of the Dead, and see also Waitkus, GM 99 (1987), p. 55 and Grimm, GM 31 (1979), pp. 27-34. It is also depicted in the third eastern Osiris chapel in the temple of Dendera in a row of protective entities in the soubassement, with two wz $\underline{d}$-signs in its hands; see Dendara, X, 1997, p. 197 and pl. 95 (no. 29).

${ }^{89}$ See Assmann, Das Grab der Mutirdis, 1977, pp. 14-15. Compare also Waitkus, GM 99 (1987), pp. 69-80 and Smith, Papyrus BM 10507, 1987, p. 25 and 28, with further literature references on this topic.

${ }^{90}$ Assmann, Das Grab der Mutirdis, 1977, pp. 90-93, with a line drawing of the scene on p. 91. For a list of other attestations of this scene, such as in the temple of Seti I at Abydos, more information on the Awakening Scene, and literature references, see Assmann, Das Grab der Mutirdis, 1977, pp. 90-93 and Teotino, in Dawson and Strudwick (eds.), Ancient Egyptian Coffins, forthcoming.

${ }^{91}$ Waitkus, GM 99 (1987), p. 71 and Assmann, Das Grab der Mutirdis, 1977, p. 14. Compare also Teotino, in Dawson et al. (eds.), Ancient Egyptian Coffins, forthcoming, who provides more detailed information on this.

92 This may be compared to the practice of drawing an apotropaic circle around something as a means of protection; compare Theis, in Beck et al. (eds.), Gebauter Raum, 2016, pp. 193-210 (reference courtesy of Holger Kockelmann). 
${ }^{93}$ Compare the examples in Erichsen, Demotisches Glossar, 1954, p. 604 and CDD_T https://oi.uchicago. edu/research/publications/demotic-dictionaryoriental-institute-university-chicago (2012), p. 85.

${ }^{94} \mathrm{P}$. Leiden I 384, col. 4,31 and 5,13. Compare the plates in de Cenival, Le mythe de l'oeil du soleil, 1988, cols. 4 and 5. Compare also Quack, SAK 33 (2005), p. 347 and Hoffmann and Quack, Anthologie der demotischen Literatur, 2007, pp. 207 and 358 (y) (reference courtesy of anonymous reviewer). The Demotic $t j$-sign is also written in the lower margin of col. 5 of that papyrus, according to Spiegelberg "Vielleicht ist dieses auch Z. 13 über die Zeile geschriebene Wort hier am Rande deutlich wiederholt"; see Spiegelberg, Der ägyptische Mythus vom Sonnenauge, 1917, p. 20.

${ }^{95}$ I am thankful to one of my anonymous reviewers for the suggestion that the oval shape of the composition may have been intended to match the shape of Eighteenth-Dynasty royal burial chambers and/or that of some sarcophagi.

${ }^{96}$ For this object, see the literature in $\mathrm{n} .23$ above.

${ }^{97}$ For the placement of Book of the Dead papyri on top of or around the mummy, see Kockelmann, Untersuchungen zu den späten Totenbuch-Handschriften auf Mumienbinden, II, 2008, pp. 232-33 and the literature cited there. See also Burkard, in BayerNiemeier (ed.), Liebieghaus-Museum alter Plastik, III, 1993, pp. 254-93 (reference courtesy of Thomas Christiansen).

\section{Bibliography}

Allen, Thomas G., The Book of the Dead or Going Forth by Day: Ideas of the Ancient Egyptians Concerning the Hereafter as Expressed in Their Own Terms (SAOC 37), Chicago 1974.

Altenmüller, Hartwig, “Götter, apotropäische”, LÄ II (1977), cols. 635-40.

Assmann, Jan, Altägyptische Totenliturgien, I: Totenliturgien in den Sargtexten des Mittleren Reiches, Heidelberg 2002.

Assmann, Jan, Das Grab der Mutirdis (AV 13), Mainz am Rhein 1977.

Boeser, Pieter A.A., Beschrijving van de Egyptische verzameling in het Rijksmuseum van Oudheden te Leiden, VII, Den Haag 1914.

Burkard, Günter, “B. Papyri”, in: Eva Bayer-Niemeier (ed.), Liebieghaus-Museum Alter Plastik. Ägyptische Bildwerke, III: Skulptur, Malerei, Papyri und Särge, Melsungen 1993, pp. 254-300.

Cauville, Sylvie, Dendara, X : les chapelles osiriennes, Le Caire 1997.

Cauville, Sylvie, Les chapelles osiriennes de Dendara: commentaire (BdE 118), Le Caire 1997.

$\mathrm{CDD}=$ Johnson, Janet H. (ed.), The Demotic Dictionary of the Oriental Institute of the University of Chicago, Chicago 2001-2013, https://oi.uchicago.edu/ research/publications/demotic-dictionary-orientalinstitute-university-chicago.

Cenival, Françoise de, Le mythe de l'oeil du soleil (DemStud 9), Sommerhausen 1988.

Clère, Jacques J., "Deux groupes inédits de geniesgardiens du quatrième prophète d'Amon Mentemhat",
BIFAO 86 (1986), pp. 99-106.

CT = Buck, Adriaan de, The Egyptian Coffin Texts, I-VII

(OIP 34, 49, 64, 67, 73, 81, 87), Chicago 1935-1961.

Daressy, Georges, "Fragments de deux cercueils de Saqqarah”, ASAE 17 (1917), pp. 1-20.

Davies, Norman de Garis, The Temple of Hibis in El Khārgeh Oasis, III: The Decoration, New York 1953.

Delvaux, Luc and Isabelle Therasse (eds.), Sarcophages: sous les étoiles de Nout, Bruxelles 2015.

Eigner, Diethelm, Die monumentalen Grabbauten der Spätzeit in der thebanischen Nekropole (UZK 6), Wien 1984.

Erichsen, Wolja, Demotisches Glossar, Kopenhagen 1954.

Gill, Ann-Katrin, “The Hieratic Ritual Books of Pawerem (P. BM EA 10252 and P. BM EA 10081) from the Late $4^{\text {th }}$ Century BC" (DPhil thesis, University of Oxford), Oxford 2016.

Goyon, Georges, La découverte des trésors de Tanis : aventures archéologiques en Egypte, Paris 1987.

Grimm, Alfred, "Dwn- $h 3 t$ und $R s-h r$ als Namen eines Torwächters in der Unterwelt: Zu zwei Beinamen des Sobek und zur Bezeichnung krokodilköpfiger Gottheiten”, GM 31 (1979), pp. 27-34.

Herbin, François R., Books of Breathing and Related Texts (Catalogue of the Books of the Dead and Other Religious Texts in the British Museum 4), London 2008.

Hoffmann, Friedhelm and Joachim Friedrich Quack, Anthologie der demotischen Literatur (EQA 4), Berlin 2007.

Jansen-Winkeln, Karl, Inschriften der Spätzeit, IV: Die 26. Dynastie, I. Psametik I.- Psametik III., Wiesbaden 2014.

Jelínková-Reymond, Eva, Les inscriptions de la statue guérisseuse de Djed-Her-le-Sauveur (BdE 23), Le Caire 1956.

Kockelmann, Holger, Untersuchungen zu den späten Totenbuch-Handschriften auf Mumienbinden, (SAT 12), Wiesbaden 2008.

Lapp, Günther, The Papyrus of Nu (Catalogue of the Books of the Dead in the British Museum 1), London 1996.

Lapp, Günther, Totenbuch Sprüche 18, 20 (Totenbuchtexte 5), Basel 2009.

Leclant, Jean, “Les génies-gardiens de Montouemhat”, in: Nina V. Pigulevskaja (ed.), Drevnij mir. sbornik statej akademiku Vasiliju Vasil'eviču Struve, Moskva 1962, pp. 104-29.

Leclant, Jean, Montouemhat : quatrième prophète d'Amon, prince de la ville (BdE 35), Le Caire 1961.

Leemans, Conradus, Aegyptische Monumenten van het Nederlandse Museum van Oudheden te Leyden, I/7, Leyden 1845.

Leitz, Christian, Der Sarg des Panehemisis in Wien (Studien zur spätägyptischen Religion 3), Wiesbaden 2011.

$L G G=$ Leitz, Christian (ed.), Lexikon der ägyptischen Götter und Götterbezeichnungen, I-VIII (OLA 110-116), Leuven 2002.

von Lieven, Alexandra, "Book of the Dead, Book of the Living: BD Spells as Temple Texts”, JEA 98 (2012), pp. 249-67.

Lucarelli, Rita, “The Guardian-Demons of the Book of the Dead", BMSAES 15 (2010), pp. 85-102, https://webarchive.nationalarchives.gov.uk/ 
ukgwa/20190801114227mp_/https://www.

britishmuseum.org/pdf/Lucarelli.pdf.

Lucarelli, Rita, "The Inhabitants of the Fourteenth Hill of Spell 149 of the Book of the Dead", in: Ludwig D. Morenz and Amr El Hawary (eds.), Weitergabe: Festschrift für die Ägyptologin Ursula Rößler-Köhler zum 65. Geburtstag (GOF 53), Wiesbaden 2015, pp. 275-91.

Lucarelli, Rita, “The So-Called Vignette of Spell 182 of the Book of the Dead”, in: Rita Lucarelli, Marcus MüllerRoth and Annik Wüthrich (eds.), Herausgehen am Tage: Gesammelte Schriften zum altägyptischen Totenbuch (SAT 17), Wiesbaden 2012, pp. 79-91.

Lüscher, Barbara, Totenbuch Spruch 1 : Nach Quellen des Neuen Reiches (KÄT 10), Wiesbaden 1986.

Maspero, Gaston, Sarcophages des époques persane et ptolémaïque, I (CG 29301-29306), Le Caire 1914.

Maspero, Gaston and Henri Gauthier, Sarcophages des époques persane et ptolémaïque, II (CG 29307-29323), Le Caire 1939.

Montet, Pierre, La nécropole royale de Tanis, I : les constructions et le tombeau d'Osorkon II à Tanis, Paris 1947.

Montet, Pierre, La nécropole royale de Tanis, II : les constructions et le tombeau de Psousennès à Tanis, Paris 1951.

Moret, Alexandre, Sarcophages de l'époque bubastite à l'époque saïte (CG 41001-41041), Le Caire 1913.

Müller-Roth, Marcus and Felicitas Weber, "Neue Quellen des Grüftebuchs (Tb 168)”, GM 226 (2010), pp. 63-76.

Pantalacci, Laure, “Wnm- hw33t : genèse et carrière d'un génie funéraire”, BIFAO 83 (1983), pp. 297-311.

Piankoff, Alexandre, The Wandering of the Soul (ERTR 6), New York 1974.

PM, I = Porter, Bertha and Rosalind L. B. Moss, Topographical Bibliography of Ancient Egyptian Hieroglyphic Texts, Reliefs, and Paintings, I: The Theban Necropolis, Oxford 1960-1964.

PM, III = Porter, Bertha, Rosalind L. B. Moss, Ethel W. Burney and Jaromír Málek, Topographical Bibliography of Ancient Egyptian Hieroglyphic Texts, Reliefs, and Paintings, III: Memphis, Oxford 1978-1981².

Quack, Joachim Friedrich, "Positionspräzise Nachträge in spätzeitlichen Handschriften”, SAK 33 (2005), pp. 343-47.

Quack, Joachim Friedrich, "Review of 'Roulin, Gilles, Le Livre de la Nuit : une composition égyptienne de l'audelà (OBO 147), Fribourg 1996”, WdO 28 (1997), pp. 177-81.

PN = Ranke, Hermann, Die ägyptischen Personennamen, Glückstadt 1935-1977.

Roberson, Joshua A., The Awakening of Osiris and the Transit of the Solar Barques: Royal Apotheosis in a Most Concise Book of the Underworld and Sky (OBO 262), Fribourg 2013.

Schmidt, Valdemar, Sarkofager, mumiekister, og mumiehylstre i det gamle Aegypten: Typologisk atlas med inledning, København 1919.

Schneider, Hans D., Beeldhouwkunst in het land van de farao's, Amsterdam 1992.

Schneider, Hans D. and Maarten J. Raven, De Egyptische Oudheid: Een inleidung aan de hand van de Egyptische verzameling in het Rijksmuseum van Oudheden te
Leiden, Den Haag 1981.

Sherbiny, Wael, Through Hermopolitan Lenses: Studies on the So-Called Book of Two Ways in Ancient Egypt (Problëg 33), Leiden 2017.

Shonkwiler, Randy, "Sheltering Wings: Birds as Symbols of Protection in Ancient Egypt", in: Rozenn BailleulLeSuer (ed.), Between Heaven and Earth: Birds in Ancient Egypt (Oriental Institute Museum Publications 35), Chicago 2012, pp. 49-57.

Sist, Loredana, "A 25th Dynasty Theban Coffin in the Museo del Vicino Oriente at Sapienza Università di Roma”, in: Alessia Amenta and Hélène Guichard (eds.), Proceedings First Vatican Coffin Conference: 19-22 June 2013, Città del Vaticano 2017, pp. 509-16.

Sist, Loredana, "Due frammenti lignei con figurazione magica”, in: Maria G. Amadasi Guzzo, Mario Liverani and Paolo Matthiae (eds.), Da Pyrgi a Mozia: Studi sull'archeologia del Mediterraneo in memoria di Antonia Ciasca (Vicino Oriente: Quaderno 3), Roma 2002, pp. 533-45.

Sist, Loredana, “Osservazioni sul sarcofago del Museo del Vicino Oriente della Sapienza decorato con sfilata 'demoniaca”, in: Igor Baglioni (ed.), Monstra I : Egitto, Vicino Oriente Antico, area storico-comparativa. Costruzione e percezione delle entità ibride e mostruose nel Mediterraneo antico (Religio: Collana di Studi del Museo delle Religioni “Raffaele Pettazzoni” 1), Roma 2013, pp. 73-83.

Smith, Mark, Catalogue of Demotic Papyri in the British Museum, III: The Mortuary Texts of Papyrus BM 10507, London 1987.

Spiegelberg, Wilhelm, Der ägyptische Mythus vom Sonnenauge (der Papyrus der Tierfabeln - "Kufi"): nach dem Leidener demotischen Papyrus I 384, Straßburg 1917.

Taylor, John, Journey Through the Afterlife: Ancient Egyptian Book of the Dead, London 2010.

Teotino, Carolina, “The Apotropaic Entourage of Osiris: The Protective Genii on Sarcophagi and Coffins of the Late and the Graeco-Roman Periods", in: Julie Dawson and Helen Strudwick (eds.), Ancient Egyptian Coffins: Past - Present - Future, Oxford 2018, forthcoming.

Theis, Christoffer, "Circulus magicus: Apotropäische Kreise in magischen Ritualen”, in: Susanne Beck, Burkhard Backes, I-Ting Liao, Henrike Simon and Alexandra Verbovsek (eds.), Gebauter Raum: Architektur - Landschaft - Mensch, Beiträge des Fünften Münchner Arbeitskreises Junge Aegyptologie (MAJA 5), 12.12. bis 14.12.2014 (GOF 62), Wiesbaden 2016, pp. 193-210.

Töpfer, Susanne, Das Balsamierungsritual: Eine (Neu-) Edition der Textkomposition Balsamierungsritual (pBoulaq 3, pLouvre 5158, pDurham $1983.11+$ pSt. Petersburg 18128) (Studien zur spätägyptischen Religion 13), Wiesbaden 2015.

Vanlathem, Marie-Paule, Oudegyptische lijkkisten en mummies - Cercueils et momies de l'Égypte ancienne, Bruxelles 1983.

Végh, Zsuzsanna, “The Transition from the Coffin Texts to the Book of the Dead: The Origin of the Glosses in Book of the Dead Spell 18”, in: Susanne Bickel and Lucía Díaz-Iglesias (eds.), Studies in Ancient Egyptian 
Funerary Literature (OLA 257), Leuven 2017, pp. 513-52.

Waitkus, Wolfgang, “Zur Deutung einiger apotropäischer Götter in den Gräbern im Tal der Königinnen und im Grabe Ramses III", GM 99 (1987), pp. 51-82.

Wilkinson, Richard H. and Nicholas Reeves, The Complete Valley of the Kings: Tombs and Treasures of Egypt's Greatest Pharaohs, London 1996.

\section{Online sources}

Bibliothèque Nationale de France, Gallica, http://gallica. bnf.fr

Totenbuchprojekt Bonn = Das altägyptische Totenbuch. Ein digitales Zeugenarchiv, http://totenbuch.awk.nrw.de

The British Museum, Collection Online, www. britishmuseum.org/collection 